\title{
Immunohistochemical study of the cellular immune response in human Pneumocystis carinii pneumonia
}

\author{
Estudo imuno-histoquímico da resposta imune celular na pneumonia humana por Pneumocystis carinii \\ Leandro Mantovani de Castro'; Carla Pagliari²; Elaine Raniero Fernandes'; Roosecelis Araújo Brasil2; Maria Irma Seixas Duarte²
}

\section{key words \\ Pneumocystis carinii \\ Immunohistochemistry \\ Cellular immune response}

\section{abstract}

Objectives: It has been experimentally demonstrated that host defense against Pneumocystis carinii depends on complex interactions within host immune response, mainly CD4 lymphocytes and alveolar macrophages. Since this is an important agent related to immunodeficiency, our purpose was to characterize the inflammatory immune response in lung from necropsy of AIDS patients. Procedures: Twenty-five necropsies with diagnosis of Pneumocystis carinii pneumonia were selected for immunohistochemical investigation of CD4 and CD8 lymphocytes, macrophages (CD68+), NK cells (CD57+) and cells expressing TNF-alpha. The immunostained cells were quantified and statistically analyzed. Results: All specimens presented a great number of cysts of Pneumocystis carinii in alveoli, as well as septal enlargement with inflammatory infiltrate constituted predominantly by lymphocytes and macrophages. CD4+ T cells were decreased in number, and CD8+ T cells, NK cells and macrophages predominated. Cells expressing TNF-alpha were frequently observed in septal inflammatory infiltrate. Conclusions: The immunosupression related to AIDS induces a reduction in the number of CD4+ T cells and influences high-level parasitism. The cell components that characterize the inflammatory infiltrate contribute to the severe lung injury of those patients. resumo

Objetivo: Trabalhos experimentais demonstram que as defesas do hospedeiro frente ao Pneumocystis carinii incluem interações complexas entre as células imunes, principalmente linfócitos TCD4+ e macrófagos alveolares. Sendo esse um agente importante associado às imunodeficiências, nosso objetivo foi caracterizar a resposta inflamatória em pulmão de necrópsias de pacientes com AIDS. Métodos: Foram selecionadas 25 necrópsias com diagnóstico de pneumonia por Pneumocystis carinii para pesquisa imuno-histoquímica de linfócitos TCD4+, TCD8+, macrófagos CD68+, células NK CD57+ e células com expressão de TNF-alfa. As células imunomarcadas foram quantificadas e analisadas estatisticamente. Resultados: Todos os espécimes evidenciaram elevado parasitismo na luz dos alvéolos. Observou-se espessamento septal com infiltrado inflamatório constituído predominantemente por linfócitos e macrófagos. Houve diminuição no número de linfócitos TCD4+ e aumento de linfócitos TCD8+, macrófagos e células NK. No septo alveolar freqüentemente observaram-se células expressando TNF-alfa. Conclusões: A imunossupressão relacionada à AIDS induz a diminuição de linfócitos TCD4+ e favorece a permanência de elevado parasitismo. Os componentes celulares que caracterizam o infiltrado inflamatório contribuem para os danos irreversíveis no pulmão desses pacientes.

\section{unitermos}

Pneumocystis carinii

Imuno-histoquimica

Resposta imune celular

\section{Introduction}

Pneumocystis carinii pneumonia (PCP) is a serious complication in individuals with impaired immune system, such as acquired immune deficiency syndrome (AIDS) patients. Genetic analysis has shown that Pneumocystis isolated from rodents has differences in gene sequence and this has prompted nomenclature changes, whereby $P$. carinii is reserved for the rat pathogen and $P$. jiroveci for the human pathogen ${ }^{(21)}$. Host defense against this organism includes complex interactions between host immune cells, mainly CD4+ $T$ cells and alveolar macrophages, which constitute

1. BSC.

2. PhD.

Work developed at the Laboratory of Transmissible Diseases Pathology - Department of Pathology at Faculdade de Medicina da Universidade de São Paulo. It was presented in XXIV Congresso

Brasileiro de Patologia - Florianópolis, Brasil (May, 2003). 
important cells in mediating the clearance of infection ${ }^{(23)}$. The role of CD4+ lymphocytes has been well demonstrated by experimental models of depletion and by the high prevalence of PCP following human immunodeficiency virus (HIV) infection ${ }^{(19,22)}$. Because of the inability to reliably culture Pneumocystis, investigations about the immune response has been developed more extensively in animal models ${ }^{(2,19)}$. Experimentally, the low number of CD4+T cells does not prevent an exuberant inflammatory response that includes perivascular infiltration with mononuclear cells, high number of CD8+ T cells and activation of alveolar macrophages. During the course of PCP several mediators are produced in the lung that can predispose the host to the development of acute lung injury ${ }^{(24)}$. Recent data suggest that this infection is still prevalent and a considerable mortality associated with this agent still exists ${ }^{(15)}$. Although the number of PCP in HIV patients has been decreasing with the introduction of highly active anti-retroviral therapy (HAART), there are many efforts to better understand the interplay of Pneumocystis and the host immune response, in order to develop new therapies. Our purpose was to characterize, by immunohistochemistry, the inflammatory response in lungs from necropsy of patients that died because of AIDS.

\section{Material and methods}

Twenty-five necropsies form AIDS patients were selected from the files of the Pathology Department of Faculdade de Medicina da Universidade de São Paulo. All specimens had been formalin-fixed and paraffin-embedded. They were selected after Pneumocystis carinii detection by Grocott staining and confirmed by immunohistochemistry with specific antibody (Dako M778). Ten specimens from normal lung of patients that died of non-respiratory diseases and that did not present histological alterations related to smoking, asthma or other infectious and inflammatory diseases were utilized as controls.

\section{Immunohistochemistry}

Four-micrometer sections were dewaxed in xylene and hydrated through a graded series of ethanol. Endogenous peroxidase was blocked with $3 \%$ hydrogen peroxide. The following primary antibodies were applied, and sections were incubated overnight at $4^{\circ} \mathrm{C}$ : mouse anti-CD4 diluted 1:1000, mouse anti-CD8 diluted 1:50, mouse anti-CD68 diluted 1:50, mouse anti-CD57 diluted 1:100 (Dako Corporation, Carpinteria, CA) and rabbit anti-TNF alpha diluted 1:100 (Genzyme, Cambridge, MA). Before the primary antibody, a preincubation with trypsin (Sigma Chemical Company, St. Louis, MO) in $0.01 \mathrm{M}$ of phosphate buffered saline (PBS) $\mathrm{pH} 7.4$ was performed to enhance antigen exposure when
anti-TNF alpha and anti-CD68 antibodies were applied. Biotinylated anti-rabbit and anti-mouse antibody was used at a dilution of 1:1000 for 30 minutes at $37^{\circ} \mathrm{C}$ (Dako Corporation, Carpinteria, CA). CD4+ and CD8+T cells were better visualized by using the catalyzed signal amplification (CSA) system (Dako Corporation) based on the peroxidasecatalyzed deposition of a biotinylated phenolic compound followed by a secondary reaction with streptavidin peroxidase ${ }^{(5)}$. 3,3-diaminobenzidine tetrahydroxychloride (Sigma) was used as chromogen and the slides were counterstained with hematoxylin. All reactions were performed with positive and negative controls. The second ones were constituted by the use of isotype controls and the omission of the primary antibody.

\section{Quantitative analysis}

Cells were quantified by counting the number of immunolabeled cells in ten randomized high-power fields for each specimen with a $x 10$ ocular lens with a square grid and a $\times 40$ objective.

\section{Statistical analysis}

The number of positive cells was statistically analyzed by using Graph Pad Prism version 3.00 for Windows (Graph Pad software, San Diego, CA, USA) to perform one-way ANOVA via the Kruskal-Wallis test with the level for significance set at $95 \%(p \leq 0.05)$.

\section{Results}

\section{Histopathologic analysis}

Septal enlargement with inflammatory infiltrate constituted predominantly by lymphocytes and macrophages was observed. Hyperplasia of type II pneumocyte and necrosis of type I pneumocyte were frequently seen. The alveolar space was filled by cysts of Pnemocystis carinii (Figure 1A).

\section{Immunophenotype characterization of inflammatory infiltrate}

PCP group was characterized by a decreased number of $C D 4+T$ cells when compared to the control group. An increased number of CD8+T cells, CD68+ macrophages and natural killer cells was observed in this group (Figures 1B and 1C). Cells expressing TNF-alpha were visualized in the inflammatory infiltrate in alveoli in all specimens of PCP group

(Figure 1D). The quantitative analysis revealed statistically significant differences between PCP and control groups when all the cell populations were analyzed (Figure 2). 


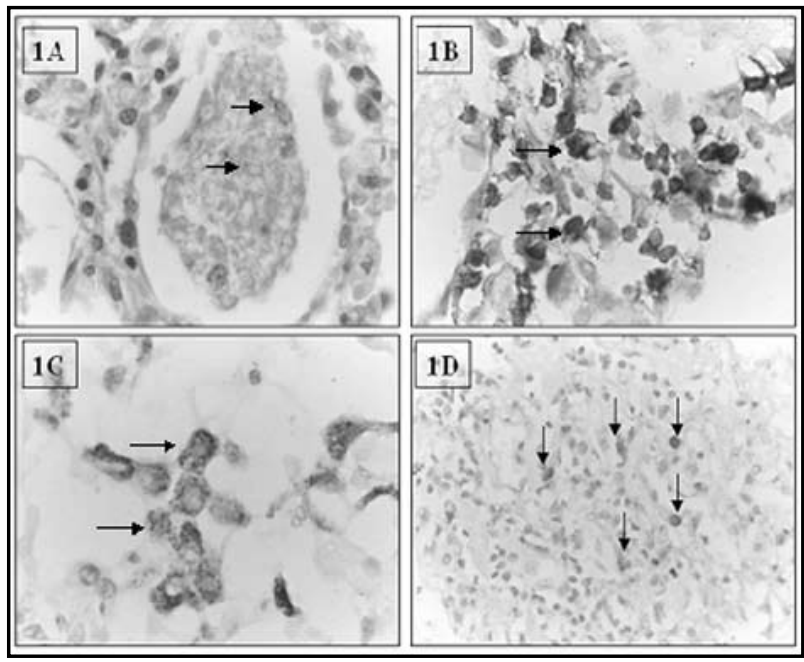

Figure 1 - Pneumocystis carinii pneumonia. A: septal enlargement with inflammatory infiltrate constituted predominantly by lymphocytes and macrophages and alveolar space filled by cysts of Pneumocystis carinii (arrows); $B$ : increased number of CD8+ T cells labeled, visualized in dark gray (arrows) (SABC/HRP method); $C$ : increased number of CD68+ macrophages, visualized in dark gray (arrows) (SABC/HRP method); D: cells expressing TNF-alpha in the inflammatory infiltrate in alveoli

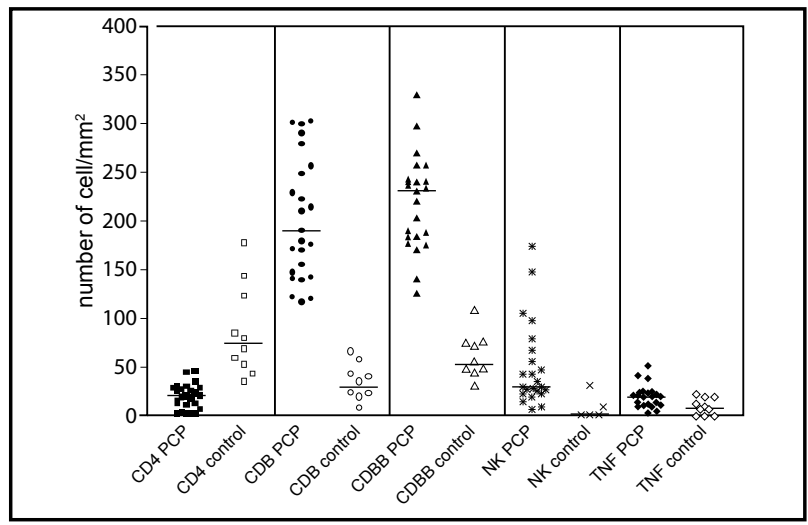

Figure 2 - Distribution of cells in the inflammatory infiltrate/mm2 in pulmonary lesions with Pneumocystis carinii and control group. Mann-Whitney test $(p<0.05)$

\section{Discussion}

Pneumocystis carinii represents an important complication of individuals with compromised immunity and the mechanisms of host defense are not totally understood. Although HAART therapy has reduced the incidence of $P C P$, it seems that the infection is delayed rather than eliminated ${ }^{(2)}$. During the course of $P C P$, inflammatory mediators are produced and exuberant inflammatory responses can predispose the host to the development of pulmonary injury ${ }^{(23)}$. Our findings evidenced histopathological characteristics that could be related to damage of pulmonary function, such as septal enlargement, alveolar space with great amount of cysts of the Pneumocystis. The reduction in the number of CD4+ $T$ cells observed in the PCP group when compared to the control group is in accordance with the protective role of these cells in the lungs that was evidenced by others ${ }^{(9)}$ and confirm that the host immune response to Pneumocystis carinii is critically dependent on these cells, that mainly act through the production of interferon gamma (IFN-gamma) for activation of the macrophages and elimination of the agent ${ }^{(9,17)}$. On the other hand, the increase in the number of CD8+ T cells could be related to the attempt of the organism to supply the levels of total T cells, which are diminished in consequence of the destruction of CD4+ T cells by HIV-dependent mechanisms. Some studies have attempted to explain which subset of cytokines (Th1 or Th2) is more important for host defense in PCP. Shellito et al. (2000) detected a higher frequency of IL4 in such response ${ }^{(20)}$. It is known that CD8+ T cells with a Tc1 profile of cytokines are important to the clearance of Pneumocystis carinii infection in the context of CD4+T cells deficiency ${ }^{(14)}$, but the absence of a Tc1 pattern can be responsible for the mediation of tissue damage ${ }^{(1,23)}$. In contrast, there is evidence suggesting that CD8+ cells cause less damage in the lungs in the absence of CD4+T cells $(8,9,18)$. This group of cells is not as investigated as CD4+ cells in host defense against Pneumocystis and future investigations seem to be important. Thus we propose to continue this investigation in order to detect the pattern of other cytokines that predominate in such lesions and cytotoxic mediators produced by CD8+ cells. The role of NK cells in the immune response against $P$ carinii is not clear, assuming that it can be present in the attempt of modulating a more effective response against this agent. Studies revealed that the percentage of CD57+ (NK) cells was significantly higher in the presence of $P$. carinii when the bronchoalveolar lavage was analyzed ${ }^{(7)}$. Our study evidenced significant amount of CD68+ macrophages in the alveolar septae and alveoli and those were the most frequent cells in the PCP cases. Many works detach the important role of macrophages in the recognition of fungi through the interaction between mannose receptor of macrophage and the gpA molecule of fungi, allowing its capture and elimination ${ }^{(10,13,16)}$. How to explain the increase in the number of macrophages without elimination of the agent? We could assume that the phagocytic function would be compromised, with reduction in the expression of mannose receptors, resulting in damage in the linking and clearance of the agent ${ }^{(4)}$. The down-regulation of the macrophage mannose receptor by HIV is described as responsible in part for the incidence of $P C P^{(6)}$. Once there is a reduction in the number of CD4+ $T$ cells and considering that CD8+ T cells and NK cells produce IFNgamma, responsible for the activation of macrophages, these cells could play a role as macrophage activating cells, not enough to allow the clearance of Pneumocystis and to prevent the development of pneumonia though. Confirming this assumption, we could detect increased number of cells with TNF-alpha expression in the PCP group. This factor is produced early and is lethal to P. carinii, 
and therefore it is one of the involved factors in the infection control ${ }^{(12,23)}$. However, this factor is also capable to increase the endothelial permeability and to contribute to pulmonary development of edema and respiratory complications, for the accumulation of leukocytes ${ }^{(11,24)}$. We consider that the increased number of cells expressing TNF-alpha that we could observe in situ in PCP would indicate the inflammatory lesive effects of this cytokine over its lethal role to $P$. carinii. It must be mentioned that CD8+ cells can increase the production of TNFalpha ${ }^{(25)}$. In view of these considerations, our results originally demonstrate in situ, in human tissue, a decreased number of $T$ CD4+ cells, a relatively increased number of T CD8+ cells, NK cells, macrophages and increased expression of TNFalpha in human PCP, what confirms the immunosupression determined by the HIV, that contribute to the permanence of high-level parasitism and the severe damages in the lung of these patients. The increased number of T CD8+ cells suggests an important role of this group of cells as a source of cytokines that can contribute to the immune response, indicating a way for further investigations in situ in human PCP.

\section{References}

I. ALLISTER, F. M. et al. T cytotoxic- I CD8+ T cells are effector cells against Pneumocystis in mice. I Immunol, v. 172, p. I |32-8, 2004

2. BECK, J. M. et al. Inflammatory responses to Pneumocystis carinii in mice selectively depleted of helper T lymphocytes. Am J Respir Cell Mol Biol, v. 5, p. I86-97, I99I.

3. BOZZETTE,S.A. et al. A randomized trial of three antipneumocystis agents in patients with advanced human immunodeficiency virus infection. New Engl I Med, v. 332, p. 693-9, 1995

4. CHEN, W.; HAVELL, E. A.; HARMSEN, A.G. Importance of endogenous tumor necrosis factor alpha and gamma interferon in host resistance against Pneumocystis carini infection. Infect Immun, v. 60, n. 4, p. 1279-84, 1992.

5. ERBER,W. N.;WILLS, J. I.; HOFFMAN, G. J.An enhanced immunocytochemical method for staining bone marrow trephine sections. J Clin Pathol, v. 50, p. 389-93, 1997.

6. FRASER, I. P. et al. Pneumocystis carinii enhances soluble mannose receptor production by macrophages. Microbes Infect, v. 2 p. I305- 10, 2000.

7. GUZMAN, J.et al. Phenotypic analysis of bronchoalveolar lavage lymphocytes from acquired immunodeficiency patients with and without Pneumocystis carinii pneumonia. Acta Cytol, v. 36, n. 6, p. 900-4, 1992

8. HANANO, R.; REIFENBERG, K.; KAUFFMANN, S. H. Naturally acquired Pneumocystis carinii pneumonia in gene disruption mutant mice: role of distinct $T$ cell populations in infection Infect Immun, v. 64, p. 3201-09, 1996.

9. HARMSEN, A.G.; STANKIEWICZ, M. Requirement for CD4+ cells in resistance to Pneumocystis carinii pneumonia in mice. J Exp Med, v. 172, n. 3, p. 937-45, 1990.

10. HOFFMAN, O.A.; STANDING, J. E.; LIMPER, A. H. Pneumocystis carinii stimulates tumor necrosis factor-alpha release from alveolar macrophages through a beta-glucan-mediated mechanism. J Immunol, v. I 50, n. 9, p. 3932-40, 1993.

I I. HYERS, T. M. et al. Tumor necrosis factor levels in serum and bronchoalveolar lavage fluid of patients with the adult respiratory distress syndrome. Am Rev Respir Dis, v. I44, n. 2, p. 268-71, 1991.

12. KOLLS, J.K. et al. Alveolar macrophage release of tumor necrosis factor during murine Pneumocystis carinii pneumonia. Am J Respir Cell Mol Biol, v. 8, n. 4, p. 370-6, 1993.

13. LIMPER, A. H.; HOYTE, J. S.; STANDING, J. E. The role of alveolar macrophages in Pneumocystis carinii degradation and clearance from the lung. Clin Invest, v. 99, n. 9, p. 2110 7, 1997.

14. MCALLISTER, F. et al. In vitro effector activity of Pneumocystis murina-specific T-cytotoxic-I CD8+ T cells: role of granulocyte-macrophage colony-stimulating factor. Infect Immun, v. 73, p.7450-7, 2005.

15. MORRIS, A. et al. Improved survival with highly active antiretroviral therapy in HIV-infected patients with severe Pneumocystis carinii pneumonia. AIDS, v. I7, p. 73-80, 2003.

16. O'RIORDAN, D. M.; STANDING, J. E.; LIMPER,A. H. Pneumocystis carinii glycoprotein A binds macrophage mannose receptors. Infect Immun, v. 63, n.3, p. 779-84, 1995

17. ROTHS, J. B. et al. Spontaneous Pneumocystis carinii pneumonia in immunodeficient mice: natural history and pathology. Am J Pathology, v. I 36, n. 5, p. I 173-86, 1990

I 8.ROTHS,J.B.;SIDMAN,C.L.Both immunity and hyperresponsiveness to Pneumocystis carinii result from transfer of CD4+ but not CD8+T cells into severe combined immunodeficiency mice. J Clin Invest, v.90, p.673-8, 1992

19. SHELLITO, J. et al. A new model of Pneumocystis carinii infection in mice selectively depleted of helper T lymphocytes. J Clin Invest, v. 85, n. 5, p. 1686-93, 1990.

20. SHELLITO, J. et al. Murine CD4+ T lymphocyte subsets and host defense against Pneumocystis carinii. Infect Dis, v. 181 , p. 20I I- 17, 2000.

21. STRINGER, J. R. Pneumocystis carinii: what is it, exactly? Clin Microbiol Rev, v. 9, p. 489-98, 1996.

22. SU, T. H.; MARTIN II, W. J. Pathogenesis and host response in Pneumocystis carinii pneumonia. Ann Rev Med, v. 45, p. 26172, 1994.

23.VASSALLO, R. et al. Mechanism of defense in the lungs: lessons from Pneumocystis carinii pneumonia. Sarcoidosis Vasc Diffuse Lung Dis, v. 17, n. 2, p. 130-9, 2000.

24. WRIGHT,T.W. et al. Immune-mediated inflammation directly impairs pulmonary function, contributing to the pathogenesis of Pneumocystis carinii pneumonia. I Clin Invest, v. 104, n. 9, p. 1307-17, 1999.

25. WRIGHT, T.W. et al. TNF receptor signaling contributes to chemokine secretion, inflammation, and respiratory deficits during Pneumocystis pneumonia. J Immunol, v. 72, n. 4, p. 25 II-2I, 2004 